Alina PREDA

Faculty of Letters, Babeş-Bolyai University

Cluj-Napoca, Romania

alinapreda74@gmail.com

\title{
CROSSING THE BOUNDARIES \\ BETWEEN MODERNIST AND POSTMODERNIST POETICS: THE CRITICAL RECEPTION OF JEANETTE WINTERSON'S NOVELS
}

Recommended Citation: Preda, Alina. "Crossing the Boundaries between Modernist and Postmodernist Poetics: The Critical Reception of Jeanette Winterson's Novels.” Metacritic Journal for Comparative Studies and Theory 5.2 (2019): https://doi.org/10.24193/mjcst.2019.8.02

Abstract: Since Jeanette Winterson's works display an electrifying combination of features, some characteristic to modernist poetics, others representative for postmodernist poetics, this paper aims to assess the oppositional critical claims that tend to assign Winterson's novels to the postmodernist trend and, respectively, to the modernist tradition, by taking into account both the author's work (fictional, as well as non-fictional) and her own self-proclaimed affiliation to modernism.

Keywords: modernism, postmodernism, taxonomic controversies, contemporary literary writing, a Wintersonian ars poetica.

The marked propensity that human beings display towards tracing patterns, identifying categories and typecasting assortments of both items and individuals is a taxonomical streak which accounts for the widespread use and abuse of labels. This profound yearning for clear-cut classifications ultimately results in a relentless discomfort affecting the taxonomically-obsessed classifier whenever some resistance to labelling is encountered, vexation that recurrently transpires into severely biased, if not unjustifiably negative reviews of the work in question. The field of literary criticism, which focuses on the work-by-work monitoring, appraisal and classification of literary writings, is no exception to this rule, as the oppositional critical claims that tend to assign Jeanette Winterson's novels to the postmodernist trend and, respectively, to the 
modernist tradition clearly demonstrate. By taking into account both the author's work (some fictional, as well as some non-fictional texts) and her own self-proclaimed affiliation to modernism, this paper aims to outline, to examine and to assess the premises on which the various dissentient interpretations of Winterson's work are grounded.

Jeanette Winterson's predilection for the intertextual foraging of Bible stories, myths, fairy tales and famous literary as well as musical works, her obvious reliance on self-reflexive interludes and meta-narrative comments that tend to blur the boundaries between the factual and the fictional, and her deconstruction of the masculine versus feminine dichotomy through the use of genderless narrators have yielded a critical consensus: although the strong influence of several modernist writers on her work has been noted, critics tend to mainly come up with analyses of Winterson as a postmodernist writer. However, Winterson's penchant for constantly re-writing well known texts and her propensity for heavily relying on intertextual techniques actually springs from T. S. Eliot's notion of tradition as outlined in "Tradition and the Individual Talent" and, to a certain extent, reflects Pierre Bourdieu's account of the modernist "constant reshuffling of values" (Rabaté 9), wherefrom the "new entrants" (Bourdieu 157) in a certain artistic field will, if remarkable enough, ultimately displace "the entire series of previous artistic acts" (Bourdieu 160). Winterson, however, does not engage in a struggle "to banish the past;" she instead endeavours to reproduce through her works, in synchronic time, past modes of artistic production, but strives to do so with a uniquely sharp twist (Bourdieu 157-158). As if she were following Harold Bloom's directive, as outlined in The Anxiety of Influence, Winterson endorses a dual approach, "honouring the exemplars while modifying their message," and this is precisely the undertaking that "creates the immanent dialectic of Modernism and the swerving pattern of history" (Jencks 145). Therefore, Jeanette Winterson frowns upon attempts to categorize her novels as postmodernist, placing herself specifically within the European tradition of experimental writing represented by Italo Calvino, Georges Perec and Milan Kundera. Her oeuvre is configured as a continuation of the late modernist project, her style is reminiscent of Ezra Pound, T. S. Eliot, D. H. Lawrence, H. D., Gertrude Stein and Virginia Woolf, whereas her approach draws on the works of Gabriel Garcia Marquez, 
Julio Cortazar and Jorge Luis Borges, enabling readers to trace "the past's configuration in the present and the present's retroaction over the past" (Berce 139).

Before 1995, when Art Objects: Essays on Ecstasy and Effrontery ${ }^{1}$ appeared, Winterson had already published five of the seven novels which, as she later explained, form her first novelistic cycle: Oranges Are Not the Only Fruit (1985) ${ }^{2}$, The Passion (1987), Sexing the Cherry (1989), Written on the Body (1992) and Art \& Lies. A Piece for Three Voices and a Bawd (1994)3. As the "quasi-homonymy" between the titles adduces, Art \& Lies is "the fictional counterpart" of Art Objects (Onega, Jeanette Winterson 132) and, together, they constitute the author's pledge of allegiance to modernism, a pledge that not even the most biased of critics can ignore. Whereas the novel was constructed as the fictional embodiment of an ars poetica, its primacy of stylistic composition disrupting plot-advancement and foregoing closure, its breadth of ideas being reminiscent of T. S. Eliot's The Waste Land, its paratactic phrasing and its sentence structure reminding readers of Gertrude Stein's vignettes, and its ingenious orchestration of the three main protagonists' voices with the discourse of the Bawd and with that of the narrator bringing to mind Virginia Woolf's The Waves, the collection of essays was meant to retrospectively present Winterson's novelistic endeavours as part of her modernist project. Entitled "A Work of My Own," the last essay in the book not only confirms the readership's feeling that this aesthetic manifesto was inspired by Virginia Woolf's work, but also clarifies the intended message that the previous novels were meant to convey.

Winterson reveals that talking about her own work is a challenging task, one best carried out by tracing the way in which it was influenced by other, most admirable writers, by stipulating the essential role that fiction and poetry are bound to play on the contemporary literary stage and by delineating the very specific albeit painstaking process of literary writing that a true wordsmith never fails to engage in. A process

\footnotetext{
${ }^{1}$ Jeanette Winterson. Art Objects: Essays on Ecstasy and Effrontery. 1995. Vintage, 1996. All subsequent references to this book will appear in parentheses in the text of the article as ( $A O$ page number).

2 Jeanette Winterson. Oranges Are Not the Only Fruit. 1985. Vintage, 1991. All subsequent references to this book will appear in parentheses in the text of the article as (Oranges page number).

3 Jeanette Winterson. Art \& Lies. A Piece for Three Voices and a Bawd. 1994. Vintage, 1995. All subsequent references to this book will appear in parentheses in the text of the article as ( $A \& L$ page number).
} 
marked by the careful selection of each expression and by the utmost precision of word usage, suited to demonstrate that the language of literature is neither inchoate, nor approximate but methodical and exact, despite the fact that it invites associations, funnels emotions and fosters speculations. This position is consistent with Jean-Michel Rabaté's views on the modernist creed concerning the purity of art as dependent upon "self-definition" and, consequently, on "a rigorous deployment of the formal properties of the medium" (6).

In her fiction, Winterson attempts to unite a kind of lyrical intensity enhanced by "variety of tone and mood," like that mastered by Tennyson and Wordsworth, and the "perfect expression of taut emotion" as displayed by Herbert and Graves, with the vigorous flow of ideas manifest in T. S. Eliot's poetry ( $A O$ 174-175). She dismisses the claim that modernism is "a kind of cul-de-sac" and insists that valuing and honouring tradition, especially through an understanding of modernism "within that tradition," are essential in order to cultivate "new forms of writing" ( $A O$ 176). Aware that, in order to gain momentum, modernist literature must keep probing and enlivening the properties of its own medium (Rabaté 8), Winterson insists that language should be used not as "a vehicle for story-telling," in journalistic fashion, but as a very precise chisel sharpened by the writer's distinctive style, able to shape "any material however unlikely" by leaving "runnels of great strength and infinite delicacy" ( $A O$ 178-180). Yet for a work to really come to life, there needs to be "a perpetual dialogue" between the great masters of style that passed away, leaving an invaluable literary legacy, and the contemporary writer admiring them: "Chisel as baton passed form hand to hand, each time re-turned," since it is used with an integrity, a discipline and a determination that yield innovative and imaginative combinations, not style as collage, but rather "style as polyphony, where the past is audible again" ( $A O$ 181).

Issuing a caveat, Winterson mentions T. S. Eliot's insistence on the interconnectedness of stylistic and emotional evolution, explaining that in order to avoid "hardening a style into a formula," which constitutes the downfall of the complacently inclined, one must follow in the footsteps of T. S. Eliot, whose "long-poem stylistic development, the journey from The Waste Land to Four Quartets, is an emotional development of a profound order" ( $A O$ 182-183). She interprets Eliot's call for "impersonality" not as a "cry against autobiography" but rather as a demand for a kind 
of "concentration away from Self" that releases a writer's own voice to be used for "more than reported speech" ( $A O$ 184-185). Winterson chooses the Indian Rope Trick metaphor to expound her somewhat paradoxical idea - perceived as odd, in the Western world, at least - that "the total realisation of the Self" requires that the artist "escape from Self," idea that she illustrated in Oranges Are Not the Only Fruit by using a strand of autobiographical writing as an experimental device meant to "create an imaginative reality sufficiently at odds with our daily reality to startle us out of it" ( $A O$ 187-188).

To the same end, Winterson used history as a device in The Passion, to stimulate the reader's immersion in the rather ravelled narrative with the lure of a nifty story. She admits to infusing her novels with story within story within story and to wielding legends, myths, folk and fairy tales, although, like Autolycus from Shakespeare's The Winter's Tale, she knows how overrated they actually are. But, for a writer "who does not use plot as an engine or a foundation" and whose readers are, therefore, required to work, these are necessary glittery morsels meant to string along the average readers who view work as "a four letter word" and who "will not understand why they should struggle through their leisure time" ( $A O$ 188-189). Another challenge, one facing the readers of Written on the Body, comes in the form of a narrator whose gender is unidentified; this deliberately-created and cunningly-maintained ambiguity is made possible due to the author's crafty construction of "a structure that is bonded by language" ( $A O$ 190). The coexistence of different discourses in this novel champions the flexibility of form and the abundance of experimentation rooted in the Renaissance and pursued during the modernist period by T. S. Eliot, Virginia Woolf and Edith Sitwell, among others, a freedom which Winterson aims to advance by breaking down "the assumed barriers between poetry and prose" to create "a form that answers to twentyfirst-century needs" ( $A O$ 191).

This kind of trespassing, together with what she calls Winterson's "reification" and "exactness of language," both attributes that result in "linguistic precision and vitality, a new way with words," prompts Lyn Pykett to acknowledge this author's modernist drive, to a certain extent, at least, before ultimately allowing the criterion of chronology to mislead her into assigning Winterson the label "post-Modernist," which she prefers to that of "postmodernist," since her work came into existence after the Modernist period (57-60). Only one year earlier, however, Brian McHale had explained 
that because postmodernism "follows from modernism, in some sense, more than it follows after modernism," the term should be seen as actually referring to a poetics that is not only "the successor of" but also "a reaction against the poetics of early twentiethcentury modernism" (5) and, essentially, the issue of periodization is secondary to the more significant question of "how and why important authors (...) have forced us to expand and broaden the term of modernism" (Rabaté 11). Thus, Pykett actually "resists Winterson's own construction, or reconstruction of her oeuvre, while raising the critical issue of how much postmodernism is a reaction to modernism, and how much a continuation of modernist practices within a contemporary context" (Makinen 4).

Literature's defamiliarization effect is brought on by writers with a passion for words, who acknowledge the otherness of literary language as distinct from the commonness of everyday language ( $A O$ 165-167). What literary writing embodies for Winterson is "an elusive chase after perfection," a Holy Grail that she might never find but that is definitely "worth chasing, even if it does not exist"; a creative effort that the readers of Sexing the Cherry, for instance, should be able to gradually track ( $A O$ 168169). Character construction and plot development are secondary to a novel's identity, because a truly great book ceases to be a mere object and transforms, once in the reader's hands, into a relationship ( $A O$ 170). But this can only happen if a perfect accord is struck among the strands of literary language: "What the writer is looking for are the relationships within language. The tensions and harmonies between word and meaning that gradually can be resolved into form" ( $A O$ 171). This search is facilitated by purposeful avid reading, highly encouraged, if not absolutely required of those undertaking the daunting task of deciphering Art \& Lies. The cultural and literary background that this novel commands, if the audience is to make sense of the fragmentary discourses that constitute it, has posed a particular challenge and has ultimately resulted in a far from enthusiastic reception of Art \& Lies, almost unanimously deemed Winterson's least inspired novel. Still, this bewildering work mirrors exactly how cognizant writers draw inspiration from a few chosen ancestors belonging to their lineage, both minor and major writers whose work embodies vitality and authenticity, because living "alongside such writers" is tantamount to living "within a complete literary tradition" ( $A O$ 172). 
Since at the time of the essays' publication Winterson's oeuvre did not yet include the last two novels in her first cycle, what she aimed to convey in those works is described on the author's website. In line with the writer's time-exploration endeavour, whose beginnings were intimated in the Deuteronomy chapter from Oranges, where time is used horizontally, only to be employed vertically as well in Sexing the Cherry, the novel GUT Symmetries (1997) constitutes a study on the "dimensionality of time," whereas The.PowerBook (2000) is "twenty-first century fiction that uses past, present and future as shifting dimensions of a multiple reality," an endeavour made both feasible and imperious by the fact that "Modernism and Post Modernism have changed the map" (jeanettewinterson.com).

As Merja Makinen pertinently points out in her meticulously conducted survey of the critical responses to this author's work, very few critics "have treated Winterson's own claims to be a modernist and the heir to Virginia Woolf, on her own terms" (Makinen 4). With the possible exception of Susana Onega, even literary critics such as Lyn Pykett, Christy L. Burns, Lisa Haines-Wright and Tracy Lynn Kyle, Kasia Boddy, Ute Kauer and Jago Morrison, who have spotted modernist nuances in Winterson's novels, "tend not to allow this to challenge their overall view of her as a postmodernist writer" (Makinen 3). Tracy Lynn Kyle and Lisa Haines-Wright traced "an intertextual conversation" between Written on the Body and Orlando, whereas Jago Morrison compared "the rapturous textuality" of Art \& Lies with The Waves, in their attempt to illustrate the impact of Virginia Woolf's work on that of Jeanette Winterson (Makinen 3). Kasia Boddy allies Winterson's reliance on similar themes with different twists and her preference for love triangles to Gertrude Stein's process of insistence, "a repetition with a difference" (Makinen 4). In her discussion of Written on the Body, Ute Kauer remains unimpressed by the heavily metaphorical and excessively poetic discourse and likens Winterson's bid to depict passion to the same struggle that D. H. Lawrence had engaged in during the modernist period, whilst Christy L. Burns admires Winterson's revolutionary use of language and considers Written on the Body an ingenious novel that "presses on the limits of language" (297) in order to reach that transubstantiation of desire and of body into word which Sappho also invokes in Winterson's next novel, Art \& Lies: "The Word terrifies. The seducing word, the insinuating word. (...) I cannot eat my words but I do. I eat the substance, bread, and I take it into me, word and substance, 
substance and word, daily communion, blessed. (...) The Word out of flux and into form" (A\&L 54-55). Burns makes the pertinent observation that this type of transubstantiation, "likened to ingestion," resonates "as a metaphor for reading" and generates comprehension, as the author's admirable wordsmithing skills "inspire desire by use of pace, parallel structure, and associative series" (299). Burns also acquiesces Winterson's perspicuous attempts to forge "a kind of fantastic language" by fusing together "her use of fantasy and her liturgical style" (278). And, in an article published two years later, the critic compares the poetic uses of language that Winterson's work displays with the distinctive style of Virginia Woolf, concluding that they both succeed in constructing language "as a substantive entity in the world, as revelation in the biblical sense" (Makinen 140).

Nevertheless, the critic who provides a more detailed analysis of the influence that modernist authors exerted on Wintersonian texts is Susana Onega. In her 1995 edited collection of essays on the interchanges between history and literature, Onega explains that Jeanette Winterson's outlook on history in the comic novel Boating for Beginners, as well as in Oranges Are Not the Only Fruit, The Passion and Sexing the Cherry, is not postmodernist but rather modernist, as her novels feature many Proustian moments marked by journeys that uncover an odd collusion between memory and perception, thus being discernibly indebted to Marcel Proust's À la recherche $d u$ temps perdu, but also to T. S. Eliot's Gerontion, where the elderly man attested that "all he can say about turning points in world history is that he was not there" (Onega, History/Storytelling 140) and suggested that history is artful and unreliable, like a beguiling woman:

I was neither at the hot gates

Nor fought in the warm rain

Nor knee deep in the salt marsh, heaving a cutlass,

Bitten by flies, fought. (...)

History has many cunning passages, contrived corridors

And issues, deceives with whispering ambitions,

Guides us by vanities. Think now

She gives when our attention is distracted 
And what she gives, gives with such supple confusions

That the giving famishes the craving. Gives too late

What's not believed in, or is still believed,

In memory only, reconsidered passion. Gives too soon

Into weak hands, what's thought can be dispensed with

Till the refusal propagates a fear (T. S. Eliot Gerontion, Lines 3-6 and 34-43).

The leitmotif in The Passion, "I'm telling you stories. Trust me." (13) and the Deuteronomy chapter in Oranges, placed precisely in the middle because, Winterson insists, this is essential for the understanding of the novel, both work to articulate the author's conception of reality, of story-telling and of history. Truthfulness, veracity and probity do not characterise history any more than they do a story. History can be just as convoluted, inconsistent and suppositious as a story, because history is often "a means of denying the past" by robbing it of its integrity, by shaping it, by ultimately customizing it to the interests of the victor so that "order is seen to prevail" (Oranges 22-23). In fact, even in stories "there is an order and a balance to be found," although everyone views and perceives things differently, thus narrating them differently; so both history and story have in common their construction as a collage of individualistic memories of the past, since "that is the way with stories; we make them what we will":

Some people say there are true things to be found, some people say all kinds of things can be proved. I don't believe them. The only thing for certain is how complicated it all is, like string full of knots. It's all there but hard to find the beginning and impossible to fathom the end. The best you can do is admire the cat's cradle, and maybe knot it up a bit more. History should be a hammock for swinging and a game for playing, the way cats play. Claw it, chew it, rearrange it and at bedtime it's still a ball of string full of knots. (...) It's an all-purpose rainy day pursuit, this reducing of stories called history (Oranges 91).

Onega explains how Winterson manages to avert "falling into the pit of subjective solipsism" in Oranges by juxtaposing "Jeanette's «real» life-story with fantasy" or, in other words, "history with story-telling" (Onega, History/Storytelling 141). The efficiency of this technique hinges on the double narrative voice: little Jeanette's perspective mingles with the adult-narrator's focalisation of past events, forging a 
narrative out of "a series of fairy tales and allegorical passages which ironically recall God's miracles and wonders, and which, like the stories in the old testament, are reported by a God-like external narrative instance that singularly recalls the narrative voice in Deuteronomy" (Onega, History/Storytelling 141). Winterson herself likened this novel to "a fiction masquerading as a memoir" ( $A O 53)$ and compared it with Virginia Woolf's Orlando - due to its concern with language, and with Gertrude Stein's Autobiography of Alice B. Toklas - since she tried to portray herself as a character in her own fiction. Winterson insists that her writing, Oranges included, is experimental, as she purposefully breaks the narrative and disrupts the chronology through chapter titles, changes of pace and inset stories - fairytales and myth fragments. Nonetheless, early reviewers and critics classified Oranges Are Not the Only Fruit as a realistic autobiographical coming-out story in the Bildungsroman form, whereas Laura Doan, Paulina Palmer, Laurel Bollinger, Isabel C. Anievas Gamallo, Ellen Brinks and Lee Talley, Tess Cosslett, and Kim Middleton Meyer, among others, analysed it as a postmodernist novel.

For Laura Doan Oranges represents the starting point of Jeanette Winterson's narrative experimentation that would later develop into a "mechanism for imagining the fruition of a postmodern lesbian existence" (148). She attributes the success of the novel as lesbian postmodernist text to Winterson's deconstruction of binaries such as light/dark, order/disorder, lost/found, good/evil, saved/fallen, believer/heathen and, especially, female/male, in which case the traditional gender division is switched, the father being depicted as measly and passive, whereas the mother is described as bossy and active. Moreover, Doan believes that the metaphor of the oranges turned into marmalade fosters the displacement of the self/world binarism, as marmalade "embodies the orange's essence" and yet "no longer resembles an orange per se" (147148), given that it "combines rind and segments, inner and outer, in a much more complex confection" (Makinen 11):

Thus the opening epigraph, a literary device predictably announcing the theme to follow, collapses inner and outer. The epigraph, taken from Mrs Beeton's cookbook, describes the process of making marmalade and states that «when thick rinds are used the top must be thoroughly skimmed, or a scum will form marring the final appearance». The 
thick rinds, evoking as they do the image of a thick skin, bring with them the danger of «scum» rising to the surface: an image that can only be seen as a kind of self-contained morality tale (Doan 147-148).

Paulina Palmer views Oranges as a unique combination between a Bildungsroman and a lesbian coming-out novel and also targets Winterson's narrative strategy, "which she sees as an essential part of the novel's meaning and not the superfluous addendum that some early critics decreed" (Makinen 30). Palmer successfully traces, in this novel, a web of connections that enable a more complex identity construction through the alternative narratives, from modernly-twisted fairy tales and myths to wondrous reworkings of Bible stories, and points out how this technique helps put forward "the postmodern thesis that no text is completely original, but always develops out of earlier, culturally known narratives" (Makinen 31):

Oranges Are Not the Only Fruit, while rejecting a unitary model of subjectivity in favour of a delineation of fantasy identities and multiple selves, also, in true postmodern spirit, envisages and depicts subjectivity itself in terms of narrativity. Jeanette, instead of uncovering a single, static identity, constructs for herself a series of shifting, fluid selves by means of the acts of storytelling and fabulation in which she engages (Palmer 101).

Laurel Bollinger and Isabel C. Anievas Gamallo also consider the novel's intertextuality and its Bildungsroman structure but, whereas the former deplores the genre's masculinist canonical format, the latter explains how Jeanette Winterson has "radically feminised the form by amalgamating its format with a lesbian «Coming Out» narrative" (Makinen 50). Bollinger describes the postmodernist parodic reliance on Bible stories in this novel as more significant than other instances of intertextuality, because it is ambivalently framed, in apposite postmodernist fashion, not primarily as that brand of mockery normally associated with parody, but rather as pastiche, "an unsatirical blend of history and story within the problematic realms of autobiography, fairy tale, and Biblical narrative - genres that typify the «cat's cradle» approach Winterson describes" (377). Gamallo focuses on the author's use of fantasy and story-telling as indicative of Winterson's "risqué experiment" (120) meant to expose the impossibility of legitimizing 
any kind of experience through "a single overarching narrative" and to make us accept that, due to "the instability and lack of finality of any narrative we construct," identity formation and representation is a laborious process and, therefore, "the self becomes a constantly shifting entity, a product of language and narratives, and ultimately, a narrative in itself" (127).

Merja Makinen points out that, although Ellen Brinks and Lee Talley "agree on the Bible being challenged through postmodern intertextuality" (40), they close in on the mother's subversive "deconstruction of a patriarchal linearity and singularity" (51) and insist that the intertextual use of Christina Rosetti's Goblin Market and Charlotte Brontë's Jane Eyre "through the mother's reading strategy" only works to ultimately "challenge heterosexual happy families" with the aim of fostering "an inclusive domestic space for the lesbian" (51). Tess Cosslett, shows Makinen, disagrees with Brinks and Talley, her take on Winterson's intertextual choices, not only the Bible but also Sir Thomas Malory's Le Morte d'Arthur and Charlotte Brontë's Jane Eyre, being that, on the one hand, they are indicative of Jeanette's sense of isolation and, on the other hand, all three "function as liberatory prototypes for the text and the narrator" because Winterson's intertextual deployment in this novel is akin to a "pirating" scheme, since she manages to skilfully appropriate these canonical texts "as part of a feminist strategy" (Makinen 41). Similarly, Makinen explains, Kim Middleton Meyer "argues for an aesthetics of plurality and uncertainty" with paradoxically liberating and empowering outcomes, concurring with other critics that this postmodernist strategy, resting on "a fluid mélange or juxtaposition" of heterogeneous stories that cross genre boundaries, thus "subverting master narratives," has given rise to a novel that "challenges the concept of a singular, bigoted, linearity of truth or meaning, and argues instead for a fluid, relative plurality of meanings" (49).

By using a mixture of postmodernist and modernist theoretical considerations to interrogate the true nature of this author's writing, a much clearer sense of the peculiar impact of modernism upon her work emerges. Since Jeanette Winterson's writing displays an electrifying combination of features, some characteristic to modernist poetics, others representative for postmodernist poetics, if Roman Jakobson's concept of "dominant," as reclaimed by Brian McHale, were to be employed in the analysis of her novels, what would become apparent is a relatively constant shift from one set of devices 
to another, yielding distinct dominance patterns whose echelons often heighten the state of taxonomical indefiniteness. Nevertheless, there are numerous elements that constantly point to a modernist epistemological poetics, such as the persistent thematisation of epistemological doubt, of the "unknowability" problem, and of referential skepticism, the transference of epistemological difficulties to the readers through the weaving of complex webs of intertextual references and through the reliance on dislocated chronology, complicated by the various strands of narrative allotted to different narrators (McHale 9), as well as the foregrounding of what Dick Higgins had termed cognitive questions: "Who and what am I in this world of which I am part and how can I make sense of it?" are queries that reverberate throughout the first Wintersonian cycle of novels, as well as throughout her more recent works. In Boating for Beginners Gloria is trying to escape the definitions and limitations that her mother imposes on her, and so is little Jeanette in Oranges Are Not the Only Fruit. Both books contain inset stories but, while in Oranges the readers encounter a heroine as Jeanette's second self, in Boating, Gloria's alter ego is a male hero, thus touting that "the true self transcends gender" (Rosemergy 252), and also anticipating the pair of male and female narrators in The Passion and in Sexing the Cherry, the narrative trio in Art \& Lies and GUT Symmetries, whilst shadowing the blurring of gender distinctions to come in Written on the Body and The Powerbook. What brings together most of the characters portrayed in this first cycle of novels, from Gloria and Jeanette to Villanelle and Henri of The Passion, from Jordan and the Dog-Woman in Sexing the Cherry to Written on the Body's genderless narrator in love with Louise, from Sappho, Handel, Picasso, in Art \& Lies, to Alice, Jove and Stella in GUT Symmetries and to Ali/x of The.PowerBook, is their dual outward-inward exploration and the pre-eminence of the quest for self, which Jeanette Winterson's fiction "so consistently dramatizes" (Rosemergy 252). The epistemological implications of the text tend to sometimes give way to ontological ones, but the former take precedence over the latter, especially in earlier works. What can be witnessed, however, is neither a smooth transition from a modernist to a postmodernist poetics, nor a sudden and definitive change of dominant, but rather an alternation of crossing and crisscrossing movements from which a sense of irresolution ensues, a "hesitation between an epistemological dominant and an ontological dominant" characteristic of texts that McHale classified as "limit-modernist" (13-14). The 
preponderance of epistemological devices (juxtaposed perspectives and multiple focalisation achieved through the joint narration undertaken by two, three or more voices; lack of plot linearity, spiralling chronology, interior monologue and limited point-of-view) and epistemological themes (illusion and reality; history, memory and truth; love and loss; life and death; time and space) is perspicuous enough to suggest that even though Winterson does not practice a brand of "straightforward or unruffled modernism," the occasional dramatisation of ontological issues (the use of unnamed and ungendered narrators and of modular or labyrinthine delineations of urban spaces, the recourse to imaginative world-projecting acts such as the framing of fantastic journeys, the employment of en abyme structures and grotesque parodies of historical, religious, medical and scientific accounts foregrounding "the fundamental ontological discontinuity between the fictional and the real") suscitates just a slight "hemorrhage of modernist poetics," and not "a fatal one" (McHale 12-14).

The experimental qualities of modernist writing undermine any view of modernism as "a singular, institutionalized concept," pointing to the merits of accounts such as that belonging to cultural theorist Pierre Bourdieu, who regarded modernism as a discursive field of distinct competing agendas "shaped into a singular entity by its dominant practitioners and subsequent critics through the foregrounding of a certain set of elements which then serve to contain, suppress or simply ignore others" (Parsons 177). Philip Tew and Alex Murray re-examined the debate around modernism and postmodernism as mirroring the opposition between high and low culture, challenging this overly reductionist account in order to show how the fundamental split between these two literary trends has led to a rather limited understanding of modernism itself. In the absence of an accurate description of the literary culture of modernism, the obstinate insistence on rigid dichotomies is likely to have a profoundly negative impact on the critical reception of borderline texts, such as Jeanette Winterson's novels, since any interpretative endeavour is bound to principles of selectivity and inevitably marred by subjectivity. For example, the range and diversity of gendered issues and of sexualityinflected concerns permeating Winterson's work have been used to justify postmodernist views of her writing. Yet, although "unconsciously gendered masculine" (Scott 2), modernism was "inextricably bound up with a politics of gender" (Nicholls 197), sexuality being a topic that quite a few modernists dwelt on, for instance D. H. 
Lawrence, T. S. Eliot and James Joyce, as well as Virginia Woolf, H.D., Gertrude Stein and Mina Loy, who all dared to "construct new forms to evoke the flux of consciousness and the erotics of mental activity" (Boone 19). So, even though "selective quotation and strategic anthologizing of a limited range of writers, and indeed a limited range of their work" were used in order to "shape a particular strand of Modernist literary thought into a singular and increasingly dominant narrative of the period" (Parsons 176), a thorough analysis will expose it as a "polyphonic, mobile, interactive, sexually charged" trend and will thus explain the emergence of literary debates on the relationship between modernism and gender, which constitutes "a historic shift in parameters" (Scott 4), especially since the examination of the intricacies marking the identity features articulated by the above-mentioned modernist writers is carried out with the help of "theoretical models that emphasise the "performative» aspects of gendered and sexual identities, often drawing upon the work of Judith Butler" (Thacker 190). Thus, neither the unwarranted accusations that she employs scholastic mannerisms or elitist narrative discourses through intricate networks of references, nor the critical material replete with gender-related arguments that seemingly point to Jeanette Winterson's being a postmodernist writer can actually constitute a good-enough reason to ultimately sever this author's modernist connection.

An unbiased analysis of Winterson's work brings to light several of the features identified by Randall Stevenson as the "earlier initiatives of modernism," among which we can count the "competition between love of words and of the world," the investigations into the workings of narrative imagination and the "focalization of the novel in the minds or private narratives of its characters," employed alongside the "abandonment of serial, chronological conventions of arrangement" (19-22). Thus, Winterson's literary writing is an example of modernist practice that can be used to challenge what many critics identified as the descent of the experimental tradition in Britain (Bradbury 86). Winterson's claim to modernism is justified by her lively insistence on modernist themes and issues, by the tendency to make recourse to experimentation in the style and structure of her novels, and by her "essentially modernist confidence in the redemptive, transformative value of art" (Kostkowska 4), all working to foster the renewal, the sustenance and the revitalization of the modernist literary tradition. 
Providing a timely and provocative challenge for those eager to tout the waning of modernism, Jeanette Winterson's work calls for a long overdue re-examination of the critics' readiness to wield an objectionable manipulation of authorial intention in order to feed their taxonomic obsession with force-fitting literary works into their trendy box of choice, even if the respective artistic creations fail to meet these or those expectations. Building on the Kantian principle of reflective judgments, which must start "from singular objects and the subject's feelings facing them" in order to later "go back to categories that give coherence, finality, and a raison d'être to the object," and generalizing it to theoretical debates on modernist works, Rabaté concludes that "there should be an experience of the text; theory is not meant to replace it or denigrate it, let alone stand higher than the personal interaction with a given object" (10). Consequently, when authors clearly state their allegiance to one cultural phenomenon or another, their claims should not be ignored by insisting that each creation fall in line with the officially approved redaction of a trend and by focusing in a painstakingly pedantic manner on only one aspect, namely whether or not the art work conforms to the respective trend's highly edited version.

\section{References:}

Berce, Sanda. "The Retroactive Canon: Constructing a Network of Modernisms." Transylvanian Review, vol. XXV, Supplement no. 1, When the Past Meets the Present. Studies in History and Culture, edited by Petronia Petrar and Elena Păcurar, 2016: 139-154.

Bloom, Harold. The Anxiety of Influence: A Theory of Poetry. Oxford University Press, 1997.

Boddy, Kasia. "Love, Again.” Times Literary Supplement, 1 September, 2000.

Bollinger, Laurel. "Models of Female Loyalty: The Biblical Ruth in Jeanette Winterson's 'Oranges Are Not the Only Fruit."' Tulsa Studies in Women's Literature, no. 13, 1994: 363-380.

Boone, Joseph Allan. Libidinal Currents: Sexuality and the Shaping of Modernism. University of Chicago Press, 1998.

Bradbury, Malcolm. Possibilities: Essays on the State of the Novel. Oxford University Press, 1973. 
METACRITIC JOURNAL FOR COMPARATIVE STUDIES AND THEORY 5.2

Burns, Christy L. "Fantastic Language: Jeanette Winterson's Recovery of the Postmodern Word." Contemporary Literature 37, no. 2, Summer 1996: 278-306.

Doan, Laura. “Jeanette Winterson's Sexing the Postmodern.” The Lesbian Postmodern, edited by Laura Doan, Columbia University Press, 1994: 137-155.

Eliot, T. S. "Tradition and the Individual Talent" (1919). Selected Prose of T. S. Eliot, edited by Frank Kermode, Faber and Faber Limited, 1975, pp. 37-44.

---. "Gerontion.” Poems, 1920. Bartleby.com, https://www.bartleby.com/199/13.html.

Gamallo, Isabel C. Anievas. "Subversive Storytelling: The Construction of Lesbian Girlhood through Fantasy and Fairy Tale in Jeanette Winterson's 'Oranges Are Not the Only Fruit." The Girl: Construction of the Girl in Contemporary Fiction by Women, edited by Ruth O. Saxton, St Martin's, 1998: 119-134.

Haines-Wright, Lisa and Tracy Lynn Kyle. "From He and She to You and Me: Grounding Fluidity, Woolf's 'Orlando' to Winterson's 'Written on the Body.' Virginia Woolf: Texts and Contexts, edited by Beth Rigel Daugherty and Eileen Barrett, Pace University, 1996: 177-182.

Jencks, Charles. Critical Modernism: Where is post-modernism going? Wiley, 2007.

Kauer, Ute. "Narration and Gender: The Role of the First-Person Narrator in Jeanette Winterson's 'Written on the Body." "I'm Telling You Stories": Jeanette Winterson and the Politics of Reading, edited by Helena Grice and Tim Woods, Rodopi, 1998: 41-52.

Kostkowska, Justyna. Ecocriticism and Women Writers. Environmentalist Poetics of Virginia Woolf, Jeanette Winterson and Ali Smith. Palgrave Macmillan, 2013.

Makinen, Merja. The Novels of Jeanette Winterson. Palgrave Macmillan, 2005.

McHale, Brian. Postmodernist Fiction. 1987. Routledge, e-book, Taylor \& Francis e-Library, 2004.

Morrison, Jago. Contemporary Fiction. Routledge, 2003.

Nicholls, Peter. Modernisms: A Literary Guide. Palgrave Macmillan, 1995.

Onega, Susana. “"I'm telling you stories. Trust me»: History/Storytelling in 'Oranges Are Not the Only Fruit.”" Telling Histories: Narrativizing History, Historicizing Literature, edited by Susana Onega, Rodopi, 1995: 135-147.

---. Jeanette Winterson. Manchester University Press, 2006. 
Palmer, Paulina. Contemporary Lesbian Writing: Dreams, Desire, Difference. Open University Press, 1993.

Parsons, Deborah. "Gender in Modernism." The Modernism Handbook, edited by Philip Tew and Andrew Murray, Continuum, 2009: 170-185.

Pykett, Lyn. "A New Way with Words? Jeanette Winterson's Post-Modernism." "I'm Telling You Stories," edited by Helena Grice and Tim Woods, Rodopi, 1998: 53-60.

Rabaté, Jean-Michel. "Introduction." A Handbook of Modernism Studies, edited by Jean-Michel Rabaté, Wiley-Blackwell, 2013: 1-13.

Rosemergy, Jan. "Navigating the Interior Journey: The Fiction of Jeanette Winterson." British Women Writing Fiction, edited by Abby H. P. Werlock, The University of Alabama Press, 2000: 248-269.

Scott, Bonnie Kime. The Gender of Modernism. Indiana University Press, 1990.

Stevenson, Randall. "Postmodernism and Contemporary Fiction in Britain." Postmodernism and Contemporary Fiction, edited by Edmund J. Smith, B. T. Batsford Ltd, 1991: 19-35.

Tew, Philip, and Andrew Murray, editors. The Modernism Handbook. Continuum, 2009.

Thacker, Andrew. "Mapping the Current Critical Landscape." The Modernism Handbook, edited by Philip Tew and Andrew Murray, Continuum, 2009: 186-198.

Winterson, Jeanette. Oranges Are Not the Only Fruit. 1985. Vintage, 1991.

---. The Passion. 1987. Penguin Books Ltd., 1988.

---. Sexing the Cherry. 1989. Vintage, 1990.

---. Written on the Body. 1992. Vintage, 1996.

---. Art \& Lies. A Piece for Three Voices and a Bawd. 1994. Vintage, 1995.

---. Art Objects: Essays on Ecstasy and Effrontery. 1995. Vintage, 1996.

---. Gut Symmetries. 1997. Granta Books, 1998.

---. The PowerBook. 2000. Vintage, 2001, http://www.jeanettewinterson.com/book/the-powerbook/ 